\title{
Azteca Breed Horse Epididymal Sperm Evaluation: A Comparison of Head, Corpus and Cauda Sperm Quality
}

\author{
Lyda Y. Parra-Forero',2, German D. Mendoza1, Alfredo Góngora², \\ Maria D. C. López Fernández³, Luis A. Cruz, Antonio J. Montiel5, Mike E. Kjelland6, \\ Adelfa D. C. García-Contreras ${ }^{1^{*}}$ \\ ${ }^{1}$ Universidad Autónoma Metropolitana, Unidad Xochimilco, México, D. F., \\ México \\ ${ }^{2}$ Departamento de Investigación Animal y Humana, Centro de Fertilidad Humana en México, \\ México, D. F., México \\ ${ }^{3}$ Unidad de Genética, Departamento de Biología, Universidad Autónoma de Madrid, Ciudad Universitaria de \\ Cantoblanco, Madrid, Spain \\ ${ }^{4}$ Instituto de Ecología A.C. de México, Veracruz, México \\ ${ }^{5}$ Centro de Reproducción y Medicina Equina, México, D. F., México \\ ${ }^{6}$ Conservation, Genetics \& Biotech, LLC, Vicksburg, MS, USA \\ Email: lyparraf19@gmail.com, gmendoza@correo.xoc.uam.mx, investigacion@centrodefertilidad.com, \\ mariadelcarmen.lopez@uam.es, luis.cruz@inecol.mx, jersain8@hotmail.com, mkjelland@hotmail.com, \\ adelfa@correo.xoc.uam.mx
}

Received 9 June 2015; accepted 22 August 2015; published 26 August 2015

Copyright (C) 2015 by authors and Scientific Research Publishing Inc.

This work is licensed under the Creative Commons Attribution International License (CC BY).

http://creativecommons.org/licenses/by/4.0/

(c) (i) Open Access

\section{Abstract}

The main objective of this study was to determine differences in sperm recovered from the three segments of the epididymis, i.e., head, corpus and cauda, using routine measurements of sperm quality and DNA fragmentation assessment. There was a larger sperm concentration $(P<0.05)$ in the head $\left(3.34 \times 10^{6} \mathrm{sperm} / \mathrm{mL}\right)$ compared with the corpus and cauda. The percentage of normal morphology was higher in the cauda but had lower motility $(P<0.05)$. The DNA fragmentation index was higher for sperm obtained from the head and body of the epididymis $(P<0.01)$ compared with the cauda. The DNA fragmentation index values were $12 \%$ higher $(P<0.01)$ using Wright stain compared with DAPI stain in sperm from the head and corpus of the epididymis, but similar in the cauda. Spermatobioscopy parameters match the maturation changes that occur in the epididymal tract with higher quality sperm being from the cauda, but with a lower concentration compared to sperm found in the head.

\footnotetext{
"Corresponding author.
}

How to cite this paper: Parra-Forero, L.Y., Mendoza, G.D., Góngora, A., López Fernández, M.D.C., Cruz, L.A., Montiel, A.J., Kjelland, M.E. and García-Contreras, A.D.C. (2015) Azteca Breed Horse Epididymal Sperm Evaluation: A Comparison of Head, Corpus and Cauda Sperm Quality. Advances in Reproductive Sciences, 3, 57-65. http://dx.doi.org/10.4236/arsci.2015.33007 
Keywords

Epididymal, Horse, Sperm, DAPI, Wright Stain, DNA Fragmentation

\section{Introduction}

The collection of epididymal sperm can be used to preserve the genetic material of animals, including humans that present an inability to ejaculate naturally because of prostration due to health problems, lack of erection, obstructive azoospermia [1] [2], and emergency or elective castrations [3]. Epididymal sperm collection has also been useful in animals that die suddenly or in the case of Equidae because of their susceptibility to gastrointestinal problems that may end with humane euthanasia and death [4].

Epididymal sperm can be useful for fertilization, either in vivo or in vitro, as it has been shown to have a high enough quality to be used in assisted reproduction procedures. Epididymal sperm viability at room temperature for the $24 \mathrm{~h}$ following an orchiectomy is important for freezing protocols [1] [5] [6]. The sperm concentrations of the samples collected from the epididymides can be similar to those of ejaculates obtained with an artificial vagina, but the quality is reduced when epididymal sperm are subjected to multiple freezing and thawing steps [7]. Pregnancy rates with epididymal sperm have varied from $8 \%$ to $92 \%$ with frozen-thawed epididymal semen and $9 \%$ to $55 \%$ with fresh epididymal semen [8]. The differences in pregnancy rates using frozen-thawed semen can be due to the following: stallion semen quality, the type of diluent utilized, and the use or removal of the seminal plasma, as well as other factors [9].

There is a lack of information in previous studies with regard to epididymal sperm quality in terms of the state of sperm DNA integrity within the epididymides. It is in the epididymides where the major morphological changes in sperm occur [10], such as chromatin condensation, due mainly to the replacement of histones by protamines in the testes [11] [12]. However, the lack of seminal plasma makes the epididymal sperm less motile than would be considered ideal for direct insemination techniques and the sperm can also be easily damaged by oxidizing agentsp [13]-[15]. Garcia-Macias et al. [16] noted that there was a greater possibility of finding sperm with damaged DNA in epididymal samples compared with samples obtained by artificial vagina. Given the aforementioned issue, it would be beneficial to identify the potential differences in sperm obtained from the different sections of the epididymis and to determine the presence of altered DNA. The primary objective of this study was to determine the epididymal sperm DNA fragmentation index for Azteca breed stallions, while also comparing DAPI (4'-6-diamidino Obtained 2-phenylindole) and Wright stain protocols.

\section{Materials and Methods}

\subsection{Epididymal Sperm Retrieval}

Elective castrations involving Azteca breed horses $(n=46)$ of 1 - 2 years of age, were performed to obtain each individual's testes and epididymides. The collected testes and epididymides were immersed in saline solution ( $\mathrm{NaCl} 0.9 \%)$, penicillin-G (100 UI/mL) and streptomycin sulfate $(100 \mathrm{mg} / \mathrm{mL})$, kept at a temperature between 4 and $8^{\circ} \mathrm{C}$, and transported to the laboratory (Figure 1), a trip of approximately $30 \mathrm{~min}$. Epididymal sperm was obtained using the technique described by Muradas et al. [17] and the tubules of the body and head were minced when necessary. More specifically, the head, body and cauda were separated with Nylon No.1 and each segment was washed with $40 \mathrm{~mL}$ of Dulbecco's Phosphate Buffered Saline (DPBS) at a temperature of $37^{\circ} \mathrm{C} \pm 2^{\circ} \mathrm{C}$ (Dulbecco’s Phosphate Buffered Saline D8662 [2], performing 3 washes for each testicle and epididymis obtained. All of the animals used in this research were treated in accordance with the Federation of Animal Science Societies (FASS) guide for use of farm animals in research and teaching [18].

\subsection{Sperm Evaluation}

On average $37 \pm 2 \mathrm{~mL}$ of DPBS containing semen was obtained from each epididymal segment. The number of sperm based on the concentration was calculated using a Neubauer Marienfield ${ }^{\circledR}$ cell counting chamber. For sperm quality evaluations, $25.4 \times 76.2 \mathrm{~mm}$ glass microscope slides $\left(\right.$ Corning $^{\circledR}$ ) and $22 \times 22 \mathrm{~mm} \# 1.5$ coverslips $\left(\right.$ Corning $\left.{ }^{\circledR}\right)$ were used. Progressive motility was evaluated using an optical light microscope $(200 \times)$ (Eclipse 


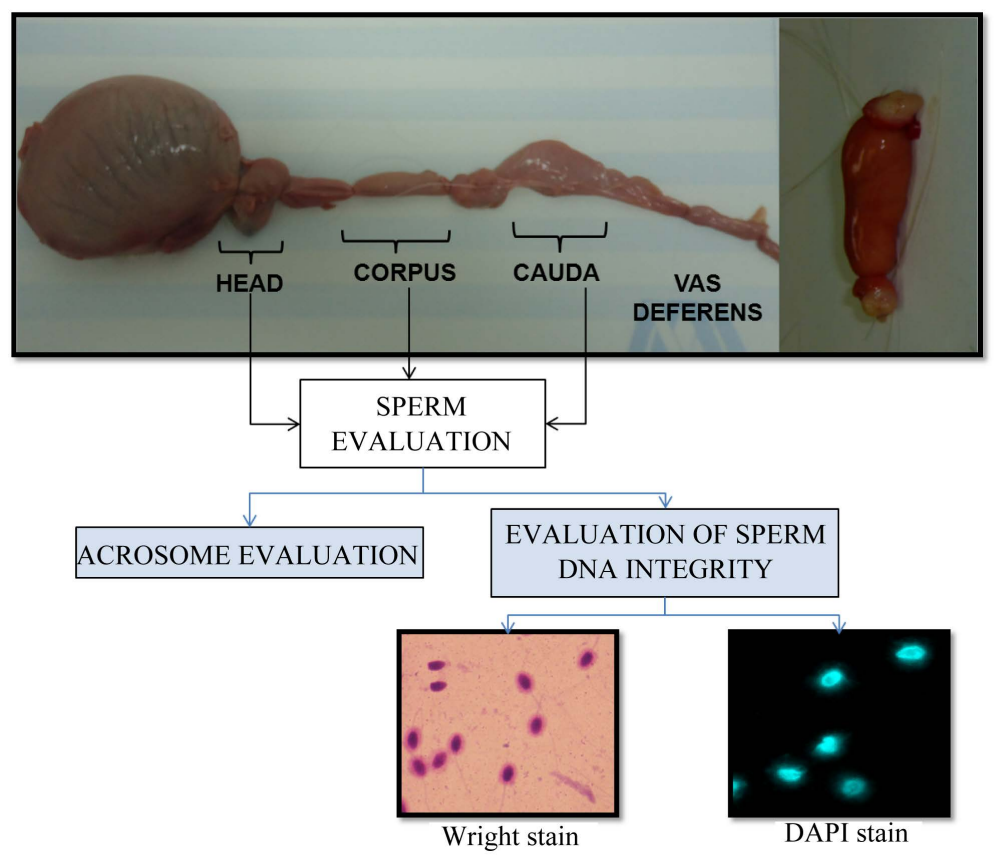

Figure 1. Azteca breed horse testicle and epididymide showing sperm DNA fragmentation analysis using Wright stain and DAPI stain.

$\mathrm{Ni}-\mathrm{U}, \mathrm{Nikon}^{\circledR}$, Japan) with $10 \mu \mathrm{L}$ of sample, sperm diluted 1:1 with DPBS. The percentage of dead sperm was determined with smears stained with eosin-nigrosin and with Diff Quick (Kubus ${ }^{\circledR}$ ) to determine the percentage of abnormal morphologies, based on [6] [13], using a 400× optical light microscope. A total of 300 cells were counted per sample (Figure 1).

\subsection{Acrosome Evaluation}

A total of $1.5 \mathrm{~mL}$ of DPBS containing collected semen was centrifuged at $50 \mathrm{~g} \times 5 \mathrm{~min}$ to obtain a sperm pellet from which $10 \mu \mathrm{L}$ were removed and diluted with $1000 \mu \mathrm{L}$ of fixing solution ( $2 \%$ paraformaldehyde, $2 \%$ formaldehyde buffered) and stored at $4^{\circ} \mathrm{C}$ until analysis [19] [20]. For the acrosome structure assessment, five washes of the sample with DPBS were performed. Afterwards, the sample was incubated for $30 \mathrm{~min}$ (while protected from light) with $10 \mathrm{uL}$ of lectin Pisum sativum (PSA) (FITC-PSA, Sigma, St Louis, MO, USA) at a 1:10,000 dilution, plus an antifade solution (Vectashield, Burlingame, USA) in a 1:1 ratio and evaluated using a fluorescence microscope (FV10i, OYMPUS) with a 1000X magnification, similar to the procedure in Farlin et al. [21].

\subsection{Evaluation of Sperm DNA Integrity}

The Halomax kit for horses (Halotech SL, Madrid, Spain) was used for assessing DNA fragmentation. The Sperm-Halomax ${ }^{\circledR}$ methodology is based on the sperm chromatin dispersion test (SCDt) [22]-[24]. Details of this technique have previously been reported for human and other mammalian species [23] [25]-[27].

In the present study, a sample of $15 \times 10^{6}$ sperm/ $\mathrm{mL}$ was diluted in agarose to give a final concentration of $1 \times$ $10^{6} \mathrm{sperm} / \mathrm{mL}$, placed in racks, lysed, and stained with DAPI (SIGMA, 4'-6-diamidino Obtained 2-phenylindole) and Wright stain (Accustain, Sigma) to obtain two slides for each epididymal segment sample. Kjelland et al. [28] provides a more detailed sperm sample preparation protocol using the Halomax kit (Figure 1). The DNA fragmentation analyses were conducted using a fluorescence microscope (FV10i, OYMPUS) using a magnification of 1000X with the DAPI stain, but without filters for the WRIGHT stain. Three hundred sperm per slide were counted to determine the sperm DNA fragmentation index which is the proportion of sperm with damaged DNA. For DNA fragmentation analysis using the Halomax kit for horses, sperm with fragmented DNA are identified by the formation of a halo around the head of the sperm produced by chromatin dispersion in agarose, 
signaling the single-strand and/or double-strand breaks in the DNA. The DNA fragments tend to move away from the sperm head with larger pieces of chromatin typically moving less distance compared to smaller pieces and thereby forming a "halo" around the sperm head. When the diameter of the halo exceeds twice the sperm head's radius then the sperm is considered fragmented [5] [22].

\subsection{Statistical Analysis}

The results of the sperm evaluation were analyzed as a completely randomized design where the model included the site of semen collection (head, corpus and cauda). The fragmentation index values of sperm assessed using DAPI and Wright stain were compared using a Student's t-test. The statistical software SPSS v. 16.0 (SPSS Inc. 2007) was used to determine the significance of the results [29] [30]. Statistical differences were determined to exist at $P<0.05$ (i.e., Type I error set at $\alpha=0.05$ ).

\section{Results}

The highest total concentration of sperm $(P<0.05)$ was found in the head of the epididymis. The percentage of normal morphology was higher in the cauda epididymis, but cauda samples also had a lower motility $(P<0.05)$ compared to the samples from the head and corpus segments. The highest percentage of damaged acrosomes was obtained in sperm from the head of the epididymis while the lowest percentage came from the cauda $(P<$ 0.05). The DNA fragmentation indices were higher in the head and corpus $(P<0.01)$ compared to the cauda (Table 1). Notably, the values obtained regarding the DNA fragmentation index were $12 \%$ higher $(P<0.01)$ using Wright stain in sperm from the head and corpus (Table 2) compared to those stained with DAPI. Figure 2 and Figure 3 show epididymal sperm stained with DAPI and Wright stain.

\section{Discussion}

Sperm maturation occurs in the tract of the epididymis, with the sperm acquiring important functions essential

Table 1. Spermatobioscopy parameters and sperm DNA fragmentation index (DNA FI) in the head, corpus, and cauda of Azteca breed horse epididymides.

\begin{tabular}{cccccc}
\hline & \multicolumn{3}{c}{ Epididymal Segment } & & \\
\hline Spermatobioscopy Parameters & Head & Corpus & Cauda & SEM & $P$-Value \\
\hline Total Concentration $\left(\times \mathbf{1 0}^{\mathbf{6}}\right)$ & $3.34^{\mathrm{a}}$ & $1.39^{\mathrm{b}}$ & $1.34^{\mathrm{b}}$ & 0.089 & $<0.0001$ \\
Motility (\%) & $69.30^{\mathrm{a}}$ & $67.02^{\mathrm{a}}$ & $54.91^{\mathrm{b}}$ & 0.873 & $<0.0001$ \\
Normal Morphology (\%) & $74.37^{\mathrm{b}}$ & $75.26^{\mathrm{b}}$ & $80.78^{\mathrm{a}}$ & 0.637 & $<0.0001$ \\
Mortality (\%) & $25.04^{\mathrm{a}}$ & $17.17^{\mathrm{b}}$ & $18.21^{\mathrm{b}}$ & 0.479 & $<0.0001$ \\
Acrosomes Damaged (\%) & $23.76^{\mathrm{a}}$ & $20.61^{\mathrm{b}}$ & $16.09^{\mathrm{c}}$ & 0.472 & $<0.0001$ \\
DNA FI DAPI & $20.96^{\mathrm{a}}$ & $20.40^{\mathrm{a}}$ & $16.47^{\mathrm{b}}$ & 0.559 & $<0.0001$ \\
DNA FI Wright & $23.48^{\mathrm{a}}$ & $23.22^{\mathrm{a}}$ & $16.72^{\mathrm{b}}$ & 0.672 & $<0.0001$ \\
\hline
\end{tabular}

Different letters indicate statistically different values, $P<0.0001$.

Table 2. Comparison of staining methods to assess the DNA fragmentation index (DNA FI) of epididymal sperm obtained from Azteca breed horses.

\begin{tabular}{cccc}
\hline & \multicolumn{3}{c}{ Stain } \\
\hline Epididymal Segment & DAPI (DNA FI) & WRIGHT (DNA FI) & $P$-Value (Student's $t$-Test) \\
\hline Head & $20.91(0.66)$ & $23.42(0.69)$ & 0.009 \\
Body & $20.35(0.52)$ & $23.16(0.82)$ & 0.005 \\
Cauda & $16.42(0.50)$ & $16.66(0.49)$ & 0.729 \\
\hline
\end{tabular}

Standard error in parentheses. 


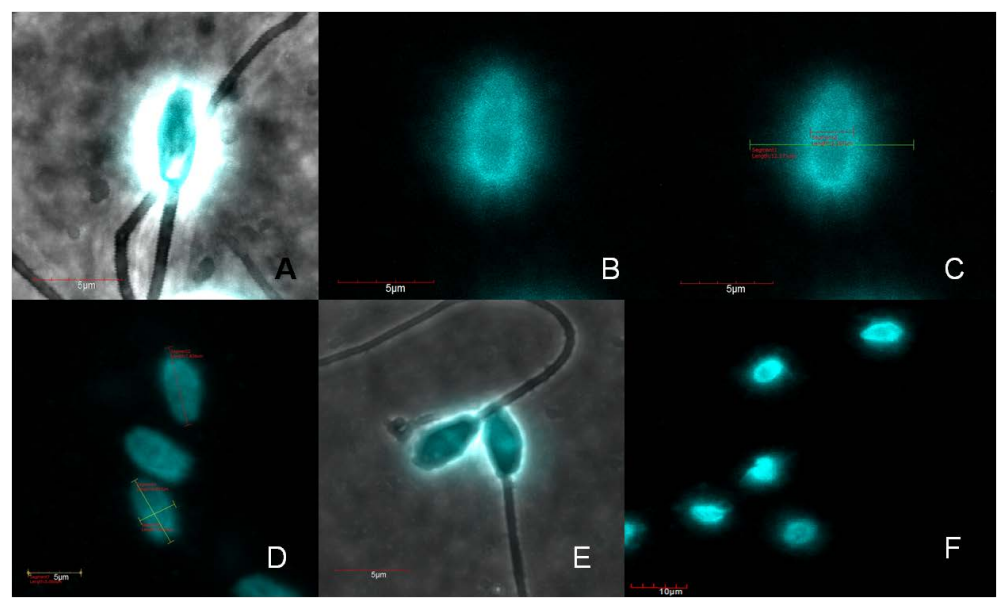

Figure 2. Azteca breed horse sperm staining with DAPI. (A) visualization of a sperm using phase contrast; (B) and (C) sperm exhibiting DNA fragmentation (fluorescence microscopy); (C) and (D) measurements of halos (fluorescence microscopy); (E) sperm without fragmentation (combination of phase contrast and fluorescence microscopy); (F) technical application of the sperm chromatin dispersion test.

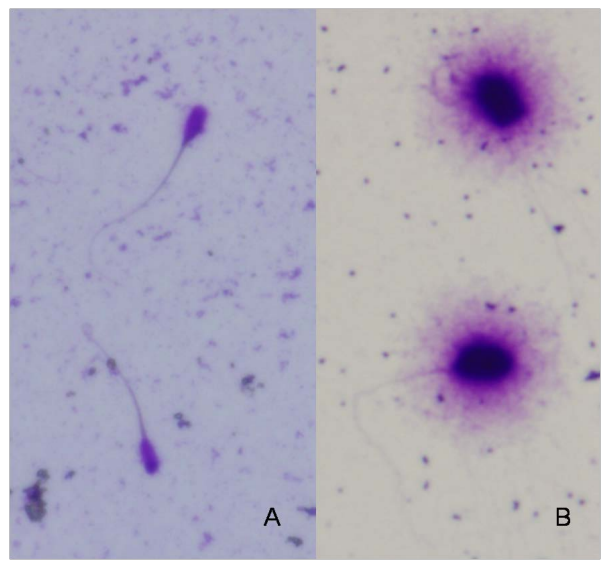

Figure 3. Azteca breed horse sperm stained with Wright stain. (A) sperm with-out fragmentation; (B) fragmented sperm.

for fertilization such as motility, differentiation of the midpiece and acrosome [11] [12] and changes and modifications to the chromatin of the nucleus [5] [13] [31]. The differences detected in the sperm collected in different segments of the epididymis reflect the biochemical changes that occur during sperm passage [32] [33]. When sperm reach the cauda they come in contact with various substances including immobiline which greatly reduces their metabolism to minimize the energy demand and minimize the occurrence of residues; primarily because the epithelium has not been developed for absorbing wastes, which are higher in the segment of the head and somewhat less in the corpus of the epididymis [33] [34].

The greater concentration of sperm was obtained from the head of the epididymis, and was higher than that reported by others, e.g., James et al. [35] and Guimarães et al. [3]. In other studies the unit of measure is given as the total sperm/ $\mathrm{mL}$ [2] [36] but they do not report the total number of mLs used for conducting the evaluation; as such, it was reported as total concentration in the present study. The differences reported for epididymal sperm concentrations in these other studies can be attributed to the differences in the age of animals and/or environmental temperatures utilized. The age of the animals and the individual effect should be considered as important variables [37] [38].

The decrease in sperm motility in the cauda segment of the epididymis has been reported by Cary et al. [39] and Braun et al. [1]. The aforementioned authors compared the motility of ejaculates obtained with an artificial 
vagina and epididymal sperm from orchiectomy on the same animals and found that cryopreserved sperm with seminal plasma produced better rates of progressive motility. Their results have been verified by several authors [3] and attributed to inhibitory factors present in the seminal plasma, which is contrary to a study by Monteiro et al. [40] who found that frozen/thawed motility values of sperm obtained from the cauda epididymis were higher than those obtained with artificial vagina ejaculates. Monteiro et al. [40] also reported that sperm obtained from the epididymis are more resistant to thermal shock and freezing, which is attributed to the different phospholipid distribution in apoptotic sperm demonstrated in the evaluation of caspase activation.

Muradas et al. [17] obtained a value of $45 \%$ live sperm with intact acrosomes recovered from the epididymis at $0 \mathrm{~h}$ of analysis (lower than that found in ejaculates, i.e., $65 \%$ at $0 \mathrm{~h}$ of analysis) and only $17 \%$ live sperm with intact acrosomes after $24 \mathrm{~h}$, indicating that these sperm can be used in reproductive clinics. The differentiation of the acrosome during spermatogenesis occurs in the tract of the epididymis, with mature sperm resulting in the end [11] [41]; this includes an intact acrosome [42] [43]. The results of the present study are in agreement with the aforementioned results, since the lowest percentage of damaged acrosomes were obtained from the cauda region of the epididymis.

The increase in dead sperm in the head of the epididymis may be due to the biochemical regionalization of the epididymis. Fouchécourt et al. [34] identified the secretion of proteins during epididymal sperm transit, with the head segment secreting the most (73\%), followed by the corpus (20.5\%), and finally the cauda $(6.5 \%)$. In the head of the epididymis, 44 different proteins were detected of which 22 were specific for this region, e.g., PGDS, GPX, and with the most abundant being the clusterines [44]-[46].

It is important to note that the horses used in this study were prepubertal, which likely affected the sperm DNA fragmentation index found in the present study. Monteiro et al. [40] reported a sperm DNA damage of 6.7\% in cryopreserved washed ejaculates and 5.7\% from epididymal sperm from adult horses. The aforementioned values are at least $10 \%$ below those found in the present study. López-Fernández et al. [22] performed sperm DNA fragmentation analysis using frozen-thawed straws of semen from stallions of various breeds and found that the average values at the time of thawing ranged between $10.3 \%$ and $25 \%$, although in that study the Azteca breed was not included.

It is necessary to consider that the physiology of each segment of the epididymis may affect the extent to which sperm DNA becomes fragmented [14] [47], with associated influence on the quality of the embryo and its implantation [8] [48]. For instance, pregnancy rates in horses with the use of epididymal sperm have ranged from $8 \%-92 \%$ [49] and this variation could be associated with sperm DNA fragmentation.

Statistically significant differences were found among the spermatobioscopy variables in different epididymal segments, meaning that there may be a higher risk of lower embryo production using sperm from one segment of the epididymis versus the other. The sperm tail must be analyzed and sperm separated by screening tests in which the largest number of immature or DNA fragmented sperm are excluded from being used in assisted reproductive techniques. Additionally, a full flushing of the epididymis, in terms of dissection of segments, is unnecessary as one would end up combining a high concentration of immature sperm with mature sperm, likely resulting in a less than ideal reproductive outcome. The epididymal sperm selection method must be conducted using such a segment selected method, most commonly the cauda, even though one sacrifices obtaining a greater volume of sperm. More advanced studies involving cultured sperm maturation should be evaluated for the head and body segments of the epididymis and the testis for Equine reproductive assisted techniques [42] [50] [51].

In a comparison of the DNA fragmentation index values using two different stains, Wright stain showed higher sperm DNA fragmentation index values than that evaluated with DAPI stain, with differences of around $12 \%(P<0.05)$. Wright stain and the HALOMAX ${ }^{\circledR}$ kit have been used in several studies using bright field microscopy [25] [52], since it contains Methylene Blue which has an affinity for proteins with a characteristic acidic property, binding to them via its positive charge thereby marking them a blue color. Given that the Wright Stain only requires bright field microscopy the sperm DNA fragmentation analysis can be much more economical than using a fluorochrome, if it would require the purchase of a microscope with fluorescence capabilities. DAPI is widely used in various techniques to detect DNA damage by its affinity to join to the nitrogenous bases adenine and thymine [25] [53] [54], although its use has declined in DNA studies as it also binds to RNA, considered as having low specificity relative to other intercalating, commercially available fluorochromes.

The two dyes, DAPI and Wright stain, have an affinity for DNA fragments and we believe that the results of the present study are not mutually exclusive, despite being statistically different (Table 2). The implementation of one or the other will be dependent upon the possibility of acquiring fluorescence microscopy capabilities. 
Studies will be needed to establish the correction for error with regard to the method of analysis of the sample, which must be conducted by individuals with other fluorochromes and different equipment characteristics found in each laboratory.

\section{Conclusion}

Some differences can be found in the characteristics of semen collected from the epididymal headcauda, and corpus; but less DNA fragmentation and less acrosome damage is observed in sperm from the cauda segment. Sperm DNA fragmentation analyses using Wright's stain result in higher DNA fragmentation index values compared with analyses made with DAPI.

\section{Conflicts of Interest}

All authors declare that there are no conflicts of interest.

\section{Acknowledgements}

This work could not have been accomplished without the support of Grant No. 327973 of CONACYT and mounted police of the City of México Dr Manuel Morones and his collaborators.

\section{References}

[1] Braun, J., Sakai, M., Hochi, S. and Oguri, N. (1994) Preservation of Ejaculated and Epididymal Stallion Spermatozoa by Cooling and Freezing. Theriogenology, 41, 809-818. http://dx.doi.org/10.1016/0093-691X(94)90497-7

[2] Bruemmer, J.E. (2006) Collection and Freezing of Epididymal Stallion Sperm. Veterinary Clinics of North America: Equine Practice, 22, 677-682. http://dx.doi.org/10.1016/j.cveq.2006.08.007

[3] Guimarães, T., Lopes, G., Ferreira, P., Leal, I. and Rocha, A. (2012) Characteristics of Stallion Epididymal Spermatozoa at Collection and Effect of Two Refrigeration Protocols on the Quality of the Frozen/Thawed Sperm Cells. Animal Reproduction Science, 136, 85-89. http://dx.doi.org/10.1016/j.anireprosci.2012.10.028

[4] Samper, J.C. (2009) Equine Breeding Management and Artificial Insemination. Elsevier Health Sciences.

[5] Ball, B.A. (2008) Diagnostic Methods for Evaluation of Stallion Subfertility: A Review. Journal of Equine Veterinary Science, 28, 650-665. http://dx.doi.org/10.1016/j.jevs.2008.10.003

[6] Betancur, G.R., Suárez, A.Ú. and Rojano, B.A. (2014) Técnicas para el análisis de la fertilidad potencial del semen equino. (Techniques for Analyzing the Potential Fertility of Stallion Semen) (Métodos de avaliação do potencial de fertilidade do sêmen equino). Revista CES Medicina Veterinaria y Zootecnia, 8, 115-127.

[7] Papa, F.O., Melo, C. and Fioratti, E. (2008) Freezing of Stallion Epididymal Sperm. Animal Reproduction Science, 107, 293-301. http://dx.doi.org/10.1016/j.anireprosci.2008.05.003

[8] Monteiro, G.A., Papa, F.O., Zahn, F.S., Dellaqua Jr., J.A., Melo, C.M., Maziero, R.R.D., Avanzi, B.R., Alvarenga, M.A. and Guasti, P.N. (2011) Cryopreservation and Fertility of Ejaculated and Epididymal Stallion Sperm. Animal Reproduction Science, 127, 197-201. http://dx.doi.org/10.1016/j.anireprosci.2011.08.002

[9] Heise, A., Thompson, P.N. and Gerber, D. (2011) Influence of Seminal Plasma on Fresh and Post-Thaw Parameters of Stallion Epididymal Spermatozoa. Animal Reproduction Science, 123, 192-201. http://dx.doi.org/10.1016/j.anireprosci.2010.11.017

[10] Dias, G., Retamal, C., Tobella, L., Arnholdt, A. and Lopez, M. (2006) Nuclear Status of Immature and Mature Stallion Spermatozoa. Theriogenology, 66, 354-365. http://dx.doi.org/10.1016/j.theriogenology.2005.10.024

[11] Clemmons, A.J., Thompson, D. and Johnson, L. (1995) Local Initiation of Spermatogenesis in the Horse. Biology of Reproduction, 52, 1258-1267. http://dx.doi.org/10.1095/biolreprod52.6.1258

[12] Baumann, C., Daly, C.M., McDonnell, S.M., Viveiros, M.M. and De La Fuente, R. (2011) Chromatin Configuration and Epigenetic Landscape at the Sex Chromosome Bivalent during Equine Spermatogenesis. Chromosoma, 120, 227244. http://dx.doi.org/10.1007/s00412-010-0306-5

[13] Varner, D.D., Blanchard, T.L., Brinsko, S.P., Love, C.C., Taylor, T.S. and Johnson, L. (2000) Techniques for Evaluating Selected Reproductive Disorders of Stallions. Animal Reproduction Science, 60-61, 493-509. http://dx.doi.org/10.1016/S0378-4320(00)00115-9

[14] Morte, M.I., Rodrigues, A.M., Soares, D., Rodrigues, A.S., Gamboa, S. and Ramalho-Santos, J. (2008) The Quantification of Lipid and Protein Oxidation in Stallion Spermatozoa and Seminal Plasma: Seasonal Distinctions and Correlations with DNA Strand Breaks, Classical Seminal Parameters and Stallion Fertility. Animal Reproduction Science, 106, 
36-47. http://dx.doi.org/10.1016/j.anireprosci.2007.03.020

[15] Toro, E., Fernández, S., Colomar, A., Casanovas, A., Álvarez, J.G., López-Teijón, M. and Velilla, E. (2009) Processing of Semen Can Result in Increased Sperm DNA Fragmentation. Fertility and Sterility, 92, 2109-2112. http://dx.doi.org/10.1016/j.fertnstert.2009.05.059

[16] Garcia-Macias, V., Martinez-Pastor, F., Alvarez, M., Garde, J.J., Anel, E., Anel, L. and de Paz, P. (2006) Assessment of Chromatin Status $\left(\mathrm{SCSA}^{\circledR}\right)$ in Epididymal and Ejaculated Sperm in Iberian Red Deer, Ram and Domestic Dog. Theriogenology, 66, 1921-1930. http://dx.doi.org/10.1016/j.theriogenology.2006.05.011

[17] Muradas, P.R., Weiss, R.R., Kozicki, L.E., Granemann, L.C., Moreira, N., Souza, J., Santos, I.W., Abreu, R.A., Green, K. and Milleo, T.C. (2013) The Viability of Cryopreserved Spermatozoa Recovered from the Cauda Epididymis of Equines and the Time of Collection Post-Orchiectomy. Asian Journal of Agriculture and Food Science.

[18] Committee, F.o.A.S.S.W. (2010) Federation of Animal Science Societies, Champaign-Urbana.

[19] Bedford, S., Varner, D. and Meyers, S. (1999) Effects of Cryopreservation on the Acrosomal Status of Stallion Spermatozoa. Journal of Reproduction and Fertility. Supplement, No. 56, 133-140.

[20] Meyers, S. (2001) Equine Sperm-Oocyte Interaction: The Role of Sperm Surface Hyaluronidase. Animal Reproduction Science, 68, 291-303. http://dx.doi.org/10.1016/S0378-4320(01)00166-X

[21] Farlin, M., Jasko, D., Graham, J. and Squires, E. (1992) Assessment of Pisum sativum Agglutinin in Identifying Acrosomal Damage in Stallion Spermatozoa. Molecular Reproduction and Development, 32, 23-27. http://dx.doi.org/10.1002/mrd.1080320105

[22] López-Fernández, C., Crespo, F., Arroyo, F., Fernández, J.L., Arana, P., Johnston, S.D. and Gosálvez, J. (2007) Dynamics of Sperm DNA Fragmentation in Domestic Animals: II. The Stallion. Theriogenology, 68, 1240-1250. http://dx.doi.org/10.1016/j.theriogenology.2007.08.029

[23] Fernández, J., Gosálvez, J., Santiso, R., Goyanes, V. and López-Fernández, C. (2008) Adaptation of the Sperm Chromatin Dispersion (SCD) Test to Determine DNA Fragmentation from Bull Sperm. New Cell Apoptosis Research. Nova Science Publishers, Inc., New York.

[24] González-Marín, C., Roy, R., López-Fernández, C., Diez, B., Carabaño, M., Fernández, J., Kjelland, M., Moreno, J. and Gosálvez, J. (2011) Bacteria in Bovine Semen Can Increase Sperm DNA Fragmentation Rates: A Kinetic Experimental Approach. Animal Reproduction Science, 123, 139-148. http://dx.doi.org/10.1016/j.anireprosci.2010.11.014

[25] Fernández, J.L., Muriel, L., Goyanes, V., Segrelles, E., Gosálvez, J., Enciso, M., LaFromboise, M. and De Jonge, C. (2005) Simple Determination of Human Sperm DNA Fragmentation with an Improved Sperm Chromatin Dispersion test. Fertility and Sterility, 84, 833-842. http://dx.doi.org/10.1016/j.fertnstert.2004.11.089

[26] Zee, Y.P., López-Fernández, C., Arroyo, F., Johnston, S.D., Holt, W.V. and Gosalvez, J. (2009) Evidence that Single-Stranded DNA Breaks Are a Normal Feature of Koala Sperm Chromatin, While Double-Stranded DNA Breaks Are Indicative of DNA Damage. Reproduction, 138, 267-278. http://dx.doi.org/10.1530/REP-09-0021

[27] Dogan, S., Vargovic, P., Oliveira, R., Belser, L.E., Kaya, A., Moura, A., Sutovsky, P., Parrish, J., Topper, E. and Memili, E. (2015) Sperm Protamine-Status Correlates to the Fertility of Breeding Bulls. Biology of Reproduction, 92, 92. http://dx.doi.org/10.1095/biolreprod.114.124255

[28] Kjelland, M., González-Marín, C., Gosálvez, J., López-Fernández, C., Lenz, R., Evans, K. and Moreno, J. (2011) DNA Fragmentation Kinetics and Postthaw Motility of Flow Cytometric-Sorted White-Tailed Deer Sperm. Journal of Animal Science, 89, 3996-4006. http://dx.doi.org/10.2527/jas.2011-4014

[29] Green, S.B. and Salkind, N.J. (2010) Using SPSS for Windows and Macintosh: Analyzing and Understanding Data. Prentice Hall Press, Upper Saddle River.

[30] Pallant, J. (2010) SPSS Survival Manual: A Step by Step Guide to Data Analysis Using SPSS. McGraw-Hill International, New York.

[31] Vieira, L., Gadea, J., García-Vázquez, F., Avilés-López, K. and Matás, C. (2013) Equine Spermatozoa Stored in the Epididymis for up to $96 \mathrm{~h}$ at $4{ }^{\circ} \mathrm{C}$ Can Be Successfully Cryopreserved and Maintain Their Fertilization Capacity. Animal Reproduction Science, 136, 280-288. http://dx.doi.org/10.1016/j.anireprosci.2012.10.027

[32] Neto, C.R., Monteiro, G.A., Soares, R.F., Pedrazzi, C., Dell’aqua Jr., J.A., Papa, F.O. and Alvarenga, M.A. (2013) Effect of Removing Seminal Plasma Using a Sperm Filter on the Viability of Refrigerated Stallion Semen. Journal of Equine Veterinary Science, 33, 40-43. http://dx.doi.org/10.1016/j.jevs.2012.04.008

[33] Monteiro, G.A., Guasti, P.N., Rocha, A.S., Martin, I., Sancler-Silva, Y.F.R., Freitas Dell’Aqua, C.P., Dell’Aqua Jr., J.A. and Papa, F.O. (2013) Effect of Storage Time and Temperature of Equine Epididymis on the Viability, Motion Parameters, and Freezability of Epididymal Sperm. Journal of Equine Veterinary Science, 33, 169-173. http://dx.doi.org/10.1016/j.jevs.2012.06.010

[34] Fouchécourt, S., Métayer, S., Locatelli, A., Dacheux, F. and Dacheux, J.-L. (2000) Stallion Epididymal Fluid Proteome: Qualitative and Quantitative Characterization; Secretion and Dynamic Changes of Major Proteins. Biology of Repro- 
duction, 62, 1790-1803. http://dx.doi.org/10.1095/biolreprod62.6.1790

[35] James, A., Green, H., Hoffman, S., Landry, A., Paccamonti, D. and Godke, R. (2002) Preservation of Equine Sperm Stored in the Epididymis at $4{ }^{\circ} \mathrm{C}$ for 24, 48, 72 and 96 Hours. Theriogenology, 58, 401-404. http://dx.doi.org/10.1016/S0093-691X(02)00883-X

[36] Monteiro, G.A., Freitas-Dell’Aqua, C.P., Guasti, P.N., Dell’Aqua Jr., J.A., Alvarenga, M.A., Landim, F.C. and Papa, F.O. (2013) Comparison of Apoptotic Cells between Cryopreserved Ejaculated Sperm and Epididymal Sperm in Stallions. Journal of Equine Veterinary Science, 33, 552-556. http://dx.doi.org/10.1016/j.jevs.2012.08.010

[37] Leme, D.P., Papa, F.O. and Roser, J.F. (2012) Reproductive Characteristics of Stallions during the Breeding and Non-Breeding Season in a Tropical Region. Tropical Animal Health and Production, 44, 1703-1707. http://dx.doi.org/10.1007/s11250-012-0127-z

[38] Claes, A., Ball, B.A., Almeida, J., Corbin, C.J. and Conley, A.J. (2013) Serum Anti-Müllerian Hormone Concentrations in Stallions: Developmental Changes, Seasonal Variation, and Differences between Intact Stallions, Cryptorchid Stallions, and Geldings. Theriogenology, 79, 1229-1235. http://dx.doi.org/10.1016/j.theriogenology.2013.03.019

[39] Cary, J.A., Madill, S., Farnsworth, K., Hayna, J.T., Duoos, L. and Fahning, M.L. (2004) A Comparison of Electroejaculation and Epididymal Sperm Collection Techniques in Stallions. The Canadian Veterinary Journal, 45, 35.

[40] Olaciregui, M., Gil, L., Monton, A., Luno, V., Jerez, R.A. and Marti, J.I. (2014) Cryopreservation of Epididymal Stallion Sperm. Cryobiology, 68, 91-95. http://dx.doi.org/10.1016/j.cryobiol.2013.12.009

[41] Johnson, L. (1995) Efficiency of Spermatogenesis. Microscopy Research and Technique, 32, 385-422. http://dx.doi.org/10.1002/jemt.1070320504

[42] Parks, J., Lee, D., Huang, S. and Kaproth, M. (2003) Prospects for Spermatogenesis in Vitro. Theriogenology, 59, 7386. http://dx.doi.org/10.1016/S0093-691X(02)01275-X

[43] Hess, R.A. and de Franca, L.R. (2009) Spermatogenesis and Cycle of the Seminiferous Epithelium. In Molecular Mechanisms in Spermatogenesis (pp. 1-15). Springer, New York. http://dx.doi.org/10.1007/978-0-387-09597-4_1

[44] Dacheux, J.-L., Castella, S., Gatti, J.L. and Dacheux, F. (2005) Epididymal Cell Secretory Activities and the Role of Proteins in Boar Sperm Maturation. Theriogenology, 63, 319-341. http://dx.doi.org/10.1016/j.theriogenology.2004.09.015

[45] Gatti, J.-L., Castella, S., Dacheux, F., Ecroyd, H., Metayer, S., Thimon, V. and Dacheux, J.-L. (2004) Post-Testicular Sperm Environment and Fertility. Animal Reproduction Science, 82, 321-339. http://dx.doi.org/10.1016/j.anireprosci.2004.05.011

[46] Dacheux, J., Belghazi, M., Lanson, Y. and Dacheux, F. (2006) Human Epididymal Secretome and Proteome. Molecular and Cellular Endocrinology, 250, 36-42. http://dx.doi.org/10.1016/j.mce.2005.12.022

[47] Sostaric, E., Aalberts, M., Gadella, B. and Stout, T.A. (2008) The Roles of the Epididymis and Prostasomes in the Attainment of Fertilizing Capacity by Stallion Sperm. Animal Reproduction Science, 107, 237-248. http://dx.doi.org/10.1016/j.anireprosci.2008.04.011

[48] Morris, L., Tiplady, C. and Allen, W. (2002) The in Vivo Fertility of Cauda Epididymal Spermatozoa in the Horse. Theriogenology, 58, 643-646. http://dx.doi.org/10.1016/S0093-691X(02)00742-2

[49] Heise, A., Kähn, W., Volkmann, D.H., Thompson, P.N. and Gerber, D. (2010) Influence of Seminal Plasma on Fertility of Fresh and Frozen-Thawed Stallion Epididymal Spermatozoa. Animal Reproduction Science, 118, 48-53. http://dx.doi.org/10.1016/j.anireprosci.2009.06.009

[50] Honaramooz, A., Snedaker, A., Boiani, M., Schöler, H., Dobrinski, I. and Schlatt, S. (2002) Sperm from Neonatal Mammalian Testes Grafted in Mice. Nature, 418, 778-781. http://dx.doi.org/10.1038/nature00918

[51] Sato, T., Katagiri, K., Gohbara, A., Inoue, K., Ogonuki, N., Ogura, A., Kubota, Y. and Ogawa, T. (2011) In Vitro Production of Functional Sperm in Cultured Neonatal Mouse Testes. Nature, 471, 504-507. http://dx.doi.org/10.1038/nature09850

[52] Enciso, M., López-Fernández, C., Fernández, J.L., García, P., Gosálbez, A. and Gosálvez, J. (2006) A New Method to Analyze Boar Sperm DNA Fragmentation under Bright-Field or Fluorescence Microscopy. Theriogenology, 65, 308316. http://dx.doi.org/10.1016/j.theriogenology.2005.05.044

[53] Sun, J.-G., Jurisicova, A. and Casper, R.F. (1997) Detection of Deoxyribonucleic Acid Fragmentation in Human Sperm: Correlation with Fertilization in Vitro. Biology of Reproduction, 56, 602-607. http://dx.doi.org/10.1095/biolreprod56.3.602

[54] Chohan, K.R., Griffin, J.T., Lafromboise, M., Jonge, C.J. and Carrell, D.T. (2006) Comparison of Chromatin Assays for DNA Fragmentation Evaluation in Human Sperm. Journal of Andrology, 27, 53-59. http://dx.doi.org/10.2164/jandrol.05068 